\title{
Companion diagnostics and the age of personalized medicine in oncology
}

\author{
Stefan Rodic, Ariel Gershon \\ Faculty Reviewer: Michael Rieder, MD, PhD, FRCPC, FAAP, FRCP(Glasgow) (Department of Paediatrics; Department of Physiology \\ \& Pharmacology; Department of Medicine)
}

\section{ABSTRACT}

Companion diagnostics are tests which are used to guide targeted therapies. They represent the application of knowledge of unique sensitivities of hosts or diseases. The FDA approved the first companion diagnostic-related drug, trastuzumab (Herceptin), in 1998. Trastuzumab is specifically effective in human epidermal growth factor receptor 2 (HER2) positive cancers, which are associated with poor outcomes with conventional cytotoxic therapy. Since trastuzumab, many other companion diagnostics have been brought to market. There are both health and economical advantages to developing companion diagnostics. With personalized therapy, patients will experience fewer and less severe side effects, and patients are more likely to have positive outcomes. Companies seeking to approve companion diagnostics will be able to recruit fewer participants for efficacy trials, leading to decreased development costs. Challenges to the future of companion diagnostics include preventing off-label usage of drugs. Additionally, the likely expensive cost of companion diagnostics, as in the example of ivacaftor (Kalydeco), will raise questions on how these drugs will be paid for.

Physicians have long recognized differences in individual treatment responses. As medicine evolves, an emphasis on personalized therapy tailored to patients based on diagnostic testing ensures maximum effectiveness. Nowhere is this trend more evident than in the rapidly evolving field of oncology, where pairings between drugs and corresponding diagnostic tests allows physicians to determine clinical utility. Companion diagnostics are the diagnostic tests employed to identify patients eligible for treatment with targeted therapies. In the case of cancer, these tests can be used to assess susceptibility of the cancer to treatment. Advances in our understanding of pathology has made the development of more specific therapies possible, moving from generalized cytotoxic cancer treatment to targeted drugs. Complementing developments in treatments, diagnostic technologies such as multiplex genotyping and high-throughput genomic profiling by next-generation sequencing now allow us to quickly analyze cancer genomes from biopsy material.

\section{PIONEERING DRUGS}

Research on companion diagnostics was first launched with FDA approval of the first companion diagnostic related treatment, trastuzumab (Herceptin), in 1998. ${ }^{1}$ By interfering with the hu- man epidermal growth factor 2 (HER2) receptor, overexpressed in around a third of breast cancers, HER2-positive patients went from having some of the worst outcomes to more favorable ones. The commercial success of trastuzumab and the corresponding diagnostic tests required for its prescription helped propel the entire field of personalized medicine forward. ${ }^{1}$ Old drugs such as tamoxifen used in estrogen receptor-positive breast cancers patients became re-evaluated. It was found that women with a CYP2D6 gene variant lacked the ability to break down the drug rendering it ineffective. ${ }^{2}$ Thus, diagnostics can be used to test not only the genomes of cancers but also of the patients themselves. Another diagnostic, TheraScreen, was launched in 2007. TheraScreen was the first diagnostic for detecting mutations in epidermal growth factor receptor (EGFR), which are known to cause non-small cell lung cancer (NSCLC). Cancers with certain mutations in EGFR are susceptible to tyrosine kinase inhibitor treatment. ${ }^{3}$ There are currently a number of Food and Drug Administration (FDA)-approved companion diagnostics (Table).

\section{ADVANTAGES}

Companion diagnostics will potentially allow therapy to be given only to the targeted population which will receive the most benefit, thus improving patient outcomes. Likewise, patients who would receive little benefit from a drug, as determined by a diagnostic assay, will not be prescribed drugs which will cause them to needlessly suffer any related drug toxicities. Through increased efficiency, the healthcare system may save costs by avoiding ineffective treatments and managing their associated side effects. A comparison of clinical trials conducted for drugs with and without companion diagnostics found that the presence of a corresponding diagnostic tool decreased the odds of treatment discontinuation as well as moderate adverse events. ${ }^{4}$

From an economic perspective, pharmaceutical companies that push drug-diagnostic pairings only have to prove that the drug is effective in the targeted population. By using only the target subset of patients in clinical trials, companies may potentially reduce development costs since drug effects will be more pronounced and a smaller number of patients will be needed to prove efficacy. The higher chance of regulatory approval significantly lowers the financial risk for pharmaceutical companies engaging in clinical trials and drug development. For example, a study of 199 compounds developed for the treatment of NSCLC found that only $11 \%$ passed the entire regulatory process, but drugs that used biomarkers to guide their administration had a $62 \%$ regulatory approval success rate. ${ }^{5}$ 
Table. Current oncological companion diagnostics ${ }^{6-8}$

\begin{tabular}{|c|c|c|c|}
\hline Indication & Drug (generic name) & Diagnostic device (type) & Diagnostic rationale \\
\hline \multirow{3}{*}{ Non-small cell lung cancer (NSCLC) } & Keytruda (pembrolizumab) & $\begin{array}{l}\text { PD-L1 IHC 22C3 pharmDx } \\
\text { (Immunohistochemical) }\end{array}$ & $\begin{array}{l}\text { Cancer expressing the inhibitory ligand PD-L1 } \\
\text { can supress the immune response, which can } \\
\text { be blocked by antibody administration. }\end{array}$ \\
\hline & $\begin{array}{l}\text { Iressa (gefitinib); } \\
\text { Gilotrif (afatinib); } \\
\text { Tarceva (erlotinib) }\end{array}$ & $\begin{array}{l}\text { Therascreen EGFR RGQ PCR Kit } \\
\text { (Real-time PCR) } \\
\text { Cobas EGFR Mutation Test (Re- } \\
\text { al-time PCR) }\end{array}$ & $\begin{array}{l}\text { Exon } 19 \text { deletions/exon } 21 \text { (L858R) substi- } \\
\text { tution mutations on EGFR gene lead to over- } \\
\text { activation of anti-apoptotic pathways. These } \\
\text { mutations indicate increased susceptibility to } \\
\text { EGFR tyrosine kinase inhibitors. }\end{array}$ \\
\hline & Xalkori (crizotinib) & $\begin{array}{l}\text { VENTANA ALK (D5F3) CDx Assay } \\
\text { (Immunohistochemical) } \\
\text { VYSIS ALK Break Apart (FISH) }\end{array}$ & $\begin{array}{l}\text { Around } 4 \% \text { of patients (typically nonsmok- } \\
\text { ers) have a fusion protein that drives malig- } \\
\text { nancy (EML4-Anaplastic lymphoma kinase). } \\
\text { This kinase is inhibited by crizotinib. }\end{array}$ \\
\hline Colorectal cancer & $\begin{array}{l}\text { Erbitux (cetuximab); Vectibix } \\
\text { (panitumumab) }\end{array}$ & $\begin{array}{l}\text { The Cobas KRAS Mutation Test } \\
\text { (Real-time PCR test) } \\
\text { Therascreen KRAS RGQ PCR Kit } \\
\text { (Real-time PCR) }\end{array}$ & $\begin{array}{l}\text { Detection of } 7 \text { somatic mutations in codons } \\
12 \text { and } 13 \text { of the KRAS gene (cell-cycle } \\
\text { regulator). These mutations are associated } \\
\text { with resistance to EGFR inhibitor therapy. } \\
\text { Treatment is only given if KRAS is negative } \\
\text { for these mutations }\end{array}$ \\
\hline Ovarian cancer & Lynparza (olaparib) & $\begin{array}{l}\text { BRACAnalysis CDx (PCR/Sanger se- } \\
\text { quencing for small variants, multiplex } \\
\text { PCR for large deletions/duplications) }\end{array}$ & $\begin{array}{l}\text { Patients with germline mutations in the DNA } \\
\text { repair enzymes BRCA1/2 are predisposed } \\
\text { to resistant forms of ovarian cancer. These } \\
\text { cancers rely on DNA repair from the PARP } \\
\text { enzyme to remain viable, which can be inhib- } \\
\text { ited by olaparib. }\end{array}$ \\
\hline Breast cancer & $\begin{array}{l}\text { Herceptin } \\
\text { (trastuzumab) }\end{array}$ & $\begin{array}{l}\text { INFORM HER-2/NEU } \\
\text { (FISH) } \\
\text { PATHWAY ANTI-HER-2/NEU (4B5) } \\
\text { (Immunohistochemical) }\end{array}$ & $\begin{array}{l}\text { Risk stratification and prognostic utility for } \\
\text { breast cancer patients. Overexpression of } \\
\text { HER2 oncogene occurs in 15-30\% of breast } \\
\text { cancers, often with more aggressive pheno- } \\
\text { types, incurring susceptibility to the HER2 } \\
\text { monoclonal antibody. }\end{array}$ \\
\hline $\begin{array}{l}\text { Breast cancer or metastatic gastric } \\
\text { or gastroesophageal junction ade- } \\
\text { nocarcinomas }\end{array}$ & $\begin{array}{l}\text { Herceptin } \\
\text { (trastuzumab); } \\
\text { Perjeta (pertuzumab); } \\
\text { Kadcyla } \\
\text { (ado-trastuzumab emtansine) }\end{array}$ & $\begin{array}{l}\text { HERCEPTEST } \\
\text { (Immunohistochemical) }\end{array}$ & $\begin{array}{l}\text { HER2 overexpression drives aggressive } \\
\text { neoplasia, susceptibility to HER2 interference } \\
\text { either by monoclonal antibody (trastuzum- } \\
\text { ab), conjugation of antibody with cytotoxic } \\
\text { DM1, or inhibition of dimerization with HER3 } \\
\text { (pertuzumab). }\end{array}$ \\
\hline $\begin{array}{l}\text { Gastrointestinal stromal tumours } \\
\text { (GIST) }\end{array}$ & $\begin{array}{l}\text { Gleevec/Glivec } \\
\text { (imatinib mesylate) }\end{array}$ & $\begin{array}{l}\text { DAKO C-KIT PharmDx } \\
\text { (Immunohistochemical) }\end{array}$ & $\begin{array}{l}\text { Mutation or overexpression in the CD117 } \\
\text { proto-oncogene drive certain GIST tumors. } \\
\text { These tumors are responsive to receptor } \\
\text { tyrosine kinase inhibitors. }\end{array}$ \\
\hline Melanoma & $\begin{array}{l}\text { Mekinist (tramatenib); } \\
\text { Tafinlar (dabrafenib); } \\
\text { Zelboraf (vemurafenib) }\end{array}$ & $\begin{array}{l}\text { Melanoma THxID BRAF Kit } \\
\text { (Real-time PCR) } \\
\text { COBAS } 4800 \text { BRAF V600 } \\
\text { (Real-time PCR) }\end{array}$ & $\begin{array}{l}\text { These drugs are only effective against tumors } \\
\text { expressing the } \mathrm{V} 600 \mathrm{E} \text { mutation of the pro- } \\
\text { to-oncogene BRAF or the rarer } \mathrm{V} 600 \mathrm{~K} \text { variant. }\end{array}$ \\
\hline
\end{tabular}

Abbreviations: CDx, companion diagnostic; FISH, fluorescence in situ hybridization; PCR, polymerase chain reaction. 


\section{CHALLENGES}

Early on there was resistance among pharmaceutical companies against pursuing companion diagnostics since they would restrict the use of the drug to a subset of patients, thereby segmenting the drug market instead of selling to a broader population. Although the regulatory-approval benefits have seemed to assuage some of these concerns, logistical issues still exist in the codevelopment of drugs and diagnostic devices. ${ }^{7}$ By adding an additional stakeholder (the diagnostic device company), the issue of negotiating development with pharmaceutical companies is further complicated. ${ }^{1}$ The costs associated with research and development of companion diagnostics and the fact that, by their nature, few people will be using the personalized pharmaceuticals means that the drugs are likely to be expensive. For instance, ivacaftor (Kalydeco) is an effective treatment for cystic fibrosis patients with the G551D mutation in the cystic fibrosis transmembrane conductance regulator (CFTR) gene but costs $\$ 300000$ per patient per year. ${ }^{10}$ Despite the cost of treatment, ivacaftor became available through Ontario's Exceptional Access Program in 2014. Another consideration is "indication creep," or the usage of drugs beyond their initial indications. For example, the FDA initially approved the use of infliximab in Crohn's disease in 1998, but it has since been expanded to treat other diseases, and there are many who use it off-label. ${ }^{11,12}$ Finally, physicians must be educated on the mechanism and clinical indications of these personalized therapies.

\section{FUTURE DIRECTIONS AND CONCLUSIONS}

Companion diagnostics may serve to be a powerful therapeutic option in the future of medicine. However, the exorbitant cost of these drugs coupled with the fact that they will be of great benefit to a select population raises questions on how they will be paid for. Although currently approved devices use single biomarkers, future diagnostics may aim to combine several biomarkers for more accurate benefit-to-risk stratification of patients for different treatments.

\section{REFERENCES}

1. Agarwal A, Ressler D, Snyder G. The current and future state of companion diagnostics. Pharmgenomics Pers Med. 2015;8:99-110.

2. Schroth W, Antoniadou L, Fritz P, Schwab M, Muerdter T, Zanger $\mathrm{UM}$, et al. Breast cancer treatment outcome with adjuvant tamoxifen relative to patient CYP2D6 and CYP2C19 genotypes. J Clin Oncol. 2007;25:5187-93.

3. Soulieres D, Greer W, Magliocco AM, Huntsman D, Young S, Tsao MS et al. KRAS mutation testing in the treatment of metastatic colorectal cancer with anti-EGFR therapies. Curr Oncol, 2010;7 Suppl 1.S31-40.

4. Ocana A, Ethier JL, Diez-Gonzalez L, Corrales-Sanchez V, Srikanthan A, Gascon-Escribano MJ, et al. Influence of companion diagnostics on efficacy and safety of targeted anti-cancer drugs: systematic review and meta-analyses. Oncotarget. 2015;6:39538-49.

5. Falconi A, Lopes G, Parker JL. Biomarkers and receptor targeted therapies reduce clinical trial risk in non-small-cell lung cancer. J Thorac Oncol.2014;9:163-9.

6. Fan YS. Companion diagnostic testing for targeted cancer therapies: an overview. Genet Test Mol Biomarkers. 2013;17:515-23.

7. Duffy MJ, Crown J. Companion biomarkers: paving the pathway to personalized treatment for cancer. Clin Chem. 2013;59:1447-56.

8. U.S Food and Drug Administration [internet]. Silver Spring (MD): U.S Food and Drug Administration;c2015. List of Cleared or Approved Companion Diagnostic Devices (In Vitro and Imaging Tools). c2015. [cited 2016 Feb 01] Available from: http://www.fda.gov/MedicalDevices/ProductsandMedicalProcedures/InVitroDiagnostics/ucm301431. htm.

9. Philip R, Carrington L, Chan M. US FDA perspective on challenges in co-developing in vitro companion diagnostics and targeted cancer therapeutics. Bioanalysis, 2011,3, 383-9.

10. Bowen KL, Gleason PP. Cystic fibrosis prevalence and total cost of care in a commercially insured population. Poster session presented at: Academy of Managed Care Pharmacy Annual Meeting, 2015 April 8-10; San Diego, CA.

11. Allen EMV, Miyake T, Gunn N, Behler CM, Kohlwes J. Off-label use of rituximab in a multipayer insurance system. JOP. 2011 Mar 1;7(2):76-9.

12. Sailler L. Rituximab off label use for difficult-to-treat auto-immune diseases: reappraisal of benefits and risks. Clin Rev Allergy Immunol. 2008 Feb;34(1):103-10. 